\title{
Understanding the role of the kynurenine pathway in human breast cancer immunobiology
}

\author{
Benjamin Heng ${ }^{1}$, Chai K. Lim ${ }^{1}$ David B. Lovejoy ${ }^{1}$, Alban Bessede², Laurence Gluch ${ }^{3}$ \\ and Gilles J. Guillemin ${ }^{1}$ \\ ${ }^{1}$ Department of Biomedical Sciences, Faculty of Medicine and Health Sciences, Macquarie University, Sydney, NSW, Australia \\ 2 ImmuSmol, Pessac, France \\ ${ }^{3}$ The Strathfield Breast Centre, Strathfield, NSW, Australia \\ Correspondence to: Gilles J. Guillemin, email: gilles.guillemin@mq.edu.au
}

Keywords: breast cancer, kynurenine pathway, immune-evasion

Received: July 13, $2015 \quad$ Accepted: November 25, 2015

Published: December 04, 2015

\section{ABSTRACT}

Breast cancer ( $\mathrm{BrCa}$ ) is the leading cause of cancer related death in women. While current diagnostic modalities provide opportunities for early medical intervention, significant proportions of breast tumours escape treatment and metastasize. Gaining increasing recognition as a factor in tumour metastasis is the local immuno-surveillance environment. Following identification of the role played by the enzyme indoleamine dioxygenase 1 (IDO1) in mediating maternal foetal tolerance, the kynurenine pathway (KP) of tryptophan metabolism has emerged as a key metabolic pathway contributing to immune escape. In inflammatory conditions activation of the KP leads to the production of several immune-modulating metabolites including kynurenine, kynurenic acid, 3-hydroxykynurenine, anthranilic acid, 3-hydroxyanthranilic acid, picolinic acid and quinolinic acid. KP over-activation was first described in BrCa patients in the early 1960s. More evidence has since emerged to suggest that the IDO1 is elevated in advanced $\mathrm{BrCa}$ patients and is associated with poor prognosis. Further, IDO1 positive breast tumours have a positive correlation with the density of immune suppressive Foxp $3+T$ regulatory cells and lymph node metastasis. The analysis of clinical microarray data in invasive BrCa compared to normal tissue showed, using two microarray databank (cBioportal and TCGA), that $86.3 \%$ and $91.4 \%$ BrCa patients have altered KP enzyme expression respectively. Collectively, these data highlight the key roles played by KP activation in $\mathrm{BrCa}$, particularly in basal BrCa subtypes where expression of most KP enzymes was altered. Accordingly, the use of KP enzyme inhibitors in addition to standard chemotherapy regimens may present a viable therapeutic approach.

\section{BREAST CANCER}

Breast cancer (BrCa) accounted for $11.9 \%$ of total worldwide cancer deaths in 2012 [1] despite recent advances in treatment and surveillance. $\mathrm{BrCa}$ is a heterogenic disease that can be categorized into four main molecular distinct subtypes based on gene expression profiling: luminal A, luminal B, human epithelial growth factor receptor-2 (HER-2) overexpressing and basal/triple negative (TN) cancer subtype [2-5] (Figure 1). A slight majority of diagnosed BrCa cases are luminal A subtype $[2,4]$ distinguished by high oestrogen receptor (ER) and/ or progesterone receptor (PR) expression, but with a low expression of the cell proliferation marker Ki-67 [2, 4].

\section{BRCA SUBTYPE MOLECULAR SIGNATURES AND ITS PROGNOSIS}

Patients diagnosed with luminal A subtype have the best prognosis as this subtype is responsive to Tamoxifen hormone therapy [6]. The luminal B subtype also expresses ER and/or PR. However, as expression of the proliferation factor $\mathrm{Ki}-67$ is higher than in the luminal A subtype, this subtype presents a higher risk of disease 
relapse [7]. HER-2 overexpressing subtype [2, 4], typically had a poor prognosis but the emergence of monoclonal antibody based therapies such as Trastuzumab, targeting the HER-2 receptor, has improved patient prognosis $(44 \%$ reduction in risk of death) [8]. The basal/TN breast cancer subtype $[2,4]$ has the highest level of proliferation-related gene expression and frequencies of genetic mutations, such as TP53 and BRCA 1 [9]. Due to the lack of targeted treatments, the basal/TN subtype has the worst prognosis. Recently, a newly established breast cancer TN subtype, claudin-low, was described $[2,4]$ and was shown to lack epithelial cell-cell adhesion proteins such as E-cadherin and claudin 3, 4 and 7 [10]. Claudin-low tumours are also characterized by low luminal, high epithelial-tomesenchymal transition features and by enhanced tumour initiating processes [11]. These properties render this subtype resistant to chemotherapy and hence these cells often dominate post-treatment tumour samples after neo-adjuvant chemotherapy or hormone therapy [12]. Patients diagnosed with this subtype also have a generally poor survival outcome [7]. Generally, each of the major subtypes comprises a roughly equal proportion of total breast cancer cases (11- 23\%).

The molecular classification of breast tumour subtype has provided new opportunities to develop more appropriately targeted therapy. However, drugbased interventions will continue to be important for $\mathrm{BrCa}$ therapy. Another significant aspect to consider is the relationship between breast tumour development and immune tolerance. A particularly interesting recent development has been the discovery of the role of IDO1 in mediating tumour immune-evasion [13]. Specifically, alterations in tryptophan catabolism in both tumour and tumour-draining lymph nodes may provide a mechanistic avenue enabling tumour-cell persistence, a view that is supported by experimental evidence [14-16]. This review will focus on the contribution that alterations in tryptophan catabolism via the kynurenine pathway (KP; Figure 2) may play in $\mathrm{BrCa}$ progression. Understanding how $\mathrm{BrCa}$ cells exploit such immune evasion mechanisms may lead to identifying promising therapeutic targets for $\mathrm{BrCa}$ and metastasis based on modulation of tryptophan metabolism.

\section{TRYPTOPHANMETABOLISM:FOCUSON THE KYNURENINE PATHWAY}

Tryptophan is an essential amino acid obtained through the diet [17]. Under physiological conditions, the majority of tryptophan is catabolized through the KP to synthesize the vital energy cofactor, nicotinamide adenine dinucleotide $\left(\mathrm{NAD}^{+}\right)$[18]. Several downstream metabolites of the KP are biologically active in various physiological and pathological processes, including kynurenine (KYN), kynurenic acid, 3-hydroxykynurenine, anthranilic acid, 3-hydroxyanthranilic acid (3-HAA), picolinic acid and quinolinic acid (QUIN).

\section{Breast cancer genetic subtypes}

\section{Differentiated}
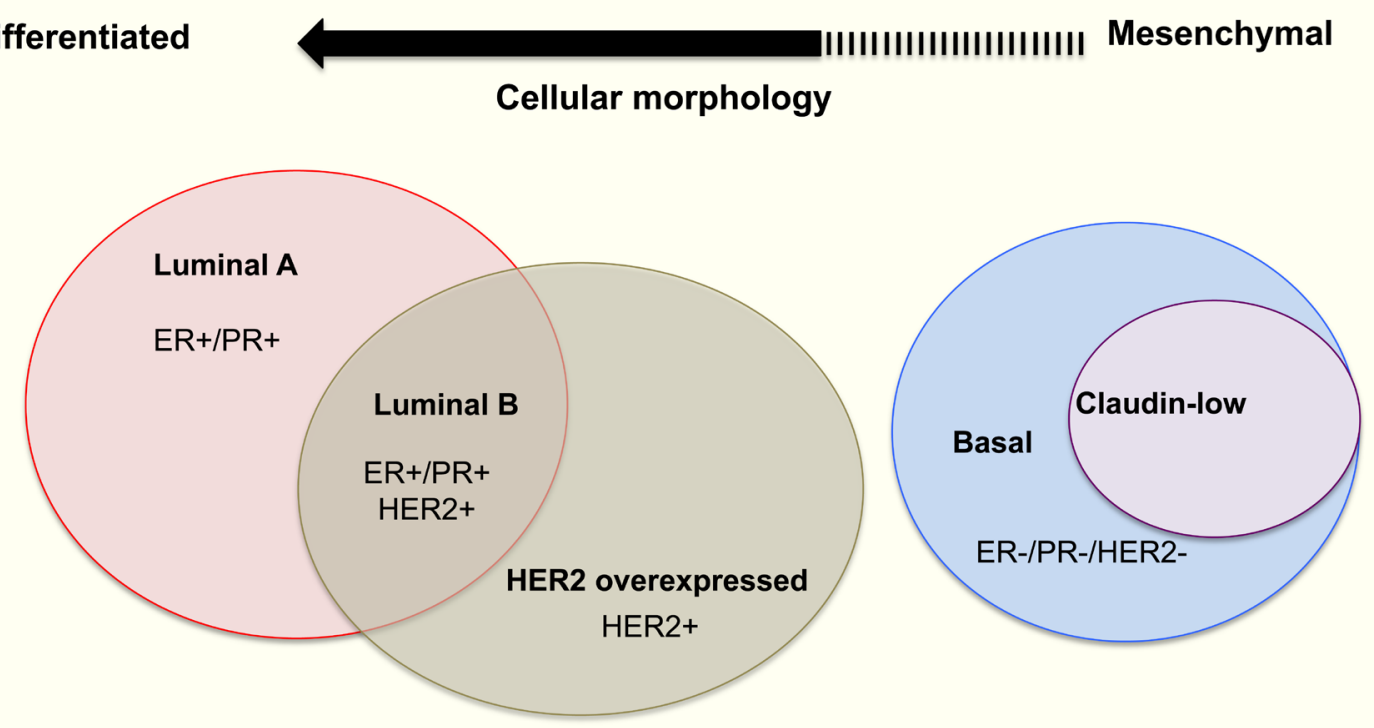

Best

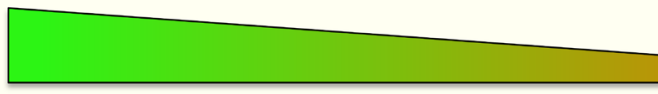

Poor

\section{Prognosis}

Figure 1: A summary of human breast cancer subtypes 
Three different heme-enzymes, indoleamine 2,3 dioxygenase 1 (IDO1) [19], indoleamine 2,3 dioxygenase 2 (IDO2) [20, 21] and tryptophan 2,3 dioxygenase (TDO2) [22], catalyse the first rate-limiting key step of the KP. Despite sharing the same substrate, the two IDO isoforms and TDO2 each have distinct inducers and patterns of tissue expression. IDO1 is highly induced by pro-inflammatory cytokines such as IFN- $\gamma$ [23] whereas TDO-2 is induced by its substrate tryptophan and by glucocorticoids [24]. Induction of IDO2, however, is less well understood. IDO1 is commonly expressed in all major organs and immune T and B cells [25], whereas IDO2 is expressed by hepatocytes, in the bile duct, neuronal cells of the cerebral cortex and dendritic cells [26]. TDO-2 is primarily expressed in the liver [27], but is also expressed in placenta [28], maternal and embryonic tissues [29], and brain [30].

A key juncture of the KP leads to the catabolism of 2-amino-3-carboxymuconate semialdehyde (ACMS) to 2-aminomuconic acid 6-semialdehyde (AMAS) by 2-amino-3-carboxymuconate semialdehyde decarboxylase (ACMSD), then AMAS non-enzymatically converts to the neuroprotective metabolite picolinic acid (Figure 2) [31]. Alternatively, the KP can branch towards the nonenzymatic rearrangement of ACMS to form the metabolite
QUIN, an essential precursor for de novo $\mathrm{NAD}^{+}$synthesis. Under normal physiological conditions, the production of picolinic acid and QUIN is at equilibrium [32]. However, during chronic activation KP metabolism is diverted towards QUIN production, and hence NAD+ biosynthesis, which may promote cellular growth.

\section{KP-MEDIATED IMMUNE-MODULATION IN CANCER}

Since the demonstration that IDO1 has immunosuppressive ability by mediating maternofetal tolerance [33], much attention has been dedicated to determining how IDO1 also modulates the immune response to tumours. In most forms of human cancers, including $\mathrm{BrCa}$, high IDO1 expression is positively correlated to poor prognosis [34-41]. Studies utilizing murine cancer models confirmed that IDO1/TDO2 over-expressing tumours are more aggressive compared to tumours with basal IDO1/ TDO2 levels $[15,16,42]$. In this paradigm, the generally pro-inflammatory cancer microenvironment leads to IDO1/TDO2 over-expression in stoma (epithelial and endothelial cells) and/or antigen-presenting cells (APCs) such as dendritic cells (DC) [43] resulting in depletion of tryptophan in the local milieu. Hence, local cytotoxic

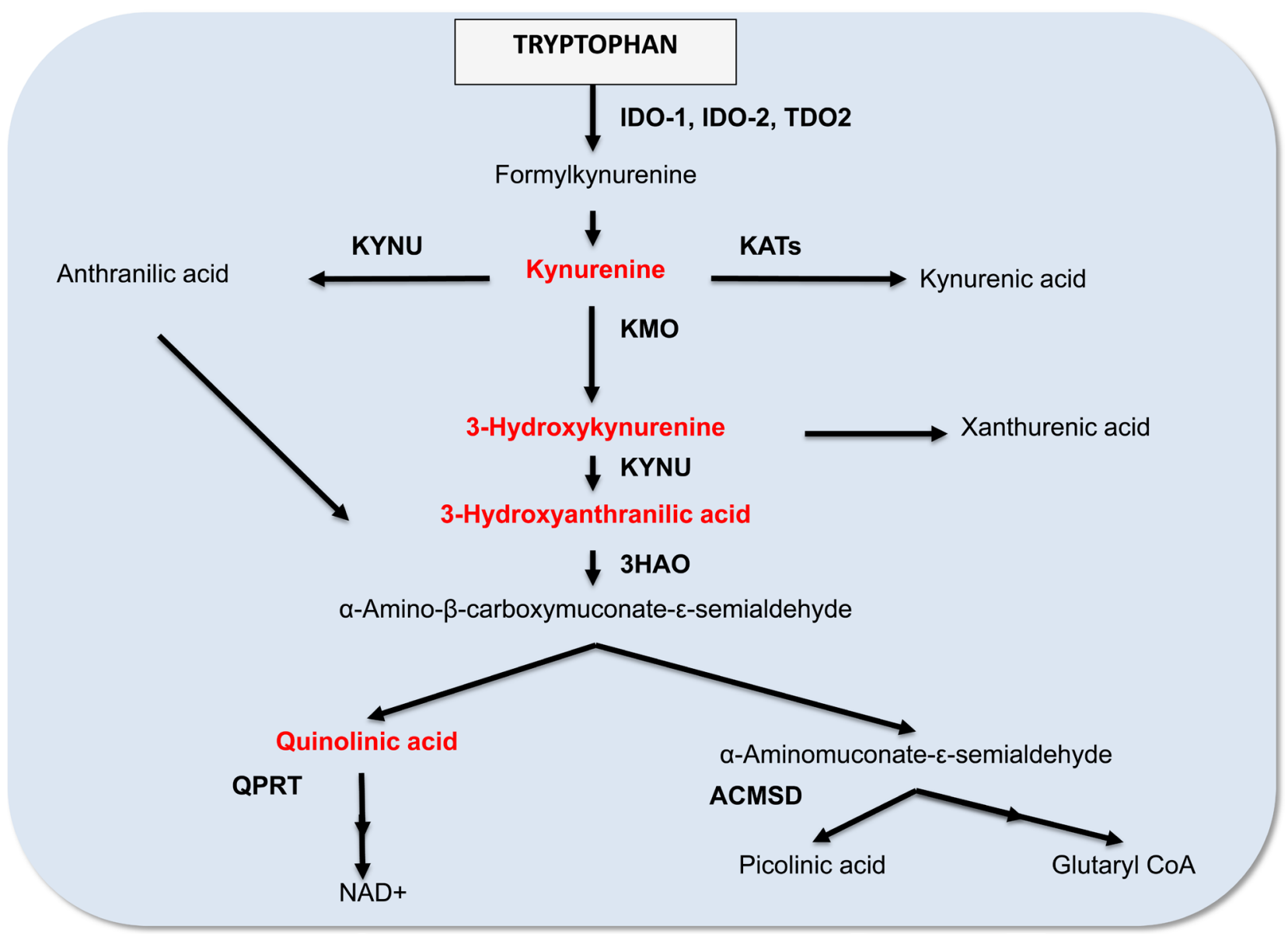

Figure 2: A simplified diagram of the kynurenine pathway. 
T-cells $\left(\mathrm{T}_{\mathrm{c}}\right)$ and $\mathrm{T}$ helper cells $\left(\mathrm{T}_{\mathrm{h}}\right)$ become tryptophan deficient leading to inhibition of proliferation as a result of general control nonderepressible 2 (GCN2) signalling pathway activation $[44,45]$. Tryptophan starvation also predisposes activated T-cells to Fas-dependent apoptosis [44, 45]. Consequently, $\mathrm{CD} 4^{+} \mathrm{CD} 25^{+}$Foxp $3^{+}$regulatory $\mathrm{T}$ cells $\left(\mathrm{T}_{\text {regs }}\right)$ mature to become the prominent T-cells population in the microenvironment [46-48]. These T-cell subset populations have a potent suppressive effect on both innate and adaptive immunity $[49,50]$. Not only do $\mathrm{T}_{\text {regs }}$ impose immuno-tolerance on the microenvironment, but they also promote immuno-tolerance in draining lymph nodes, thereby potentiating the likelihood of distant metastasis, a phenomenon that has been observed in several cancer types and is a significant ongoing problem in $\mathrm{BrCa}$ (Figure 3).

In vivo studies using various animal models of human cancers treated with IDO inhibitors have provided relevant proof-of-concept that tryptophan metabolism is involved in tumour immune-escape. Two initial studies by Uyttenhove et al. [16] and Friberg et al. [51] demonstrated that the IDO inhibitor 1-methyltryptophan (1-MT), limited the growth of IDO1 overexpressing tumours engrafted in a syngeneic host. Further studies by Muller et al. [42] confirmed that 1-MT modestly slowed the growth of spontaneous mammary tumours in MMTV/neu mice. When combined with the cancer chemotherapeutic drug paclitaxel, MMTV/neu tumour size regressed by $30 \%$ with no side effects observed [42]. This suggested that 1-MT has only limited efficacy as a monotherapy, but is effective in combination together with chemotherapy. Additionally, immunodepletion of CD4+ or CD8+ T-cells before treatment abolished the efficacy of 1-MT treatment, suggesting that the anti-tumoral efficacy of 1-MT is dependent on a specific T-lymphocyte response.

While the majority of studies support the tumourpromoting activity of IDO1, it is important to note that other studies suggest that IDO1 may have anti-tumour activity [52]. These studies demonstrated that IFN- $\gamma$ induced IDO1 resulted in depletion of the essential metabolite tryptophan, presumably reducing $\mathrm{NAD}^{+}$ production within the tumour cell thereby limiting cell growth. Animal studies have shown that IFN- $\gamma$ induced IDO1 restricted tumour growth $[53,54]$ and while clinical studies have shown that hepatocellular and renal cell carcinoma specimens evidenced a positive association between IDO1 expression and favourable outcomes [55, 56]. However, both clinical studies noted that IDO1 expression was restricted to tumour infiltrating cells but was not found in the tumour cells. This potentially

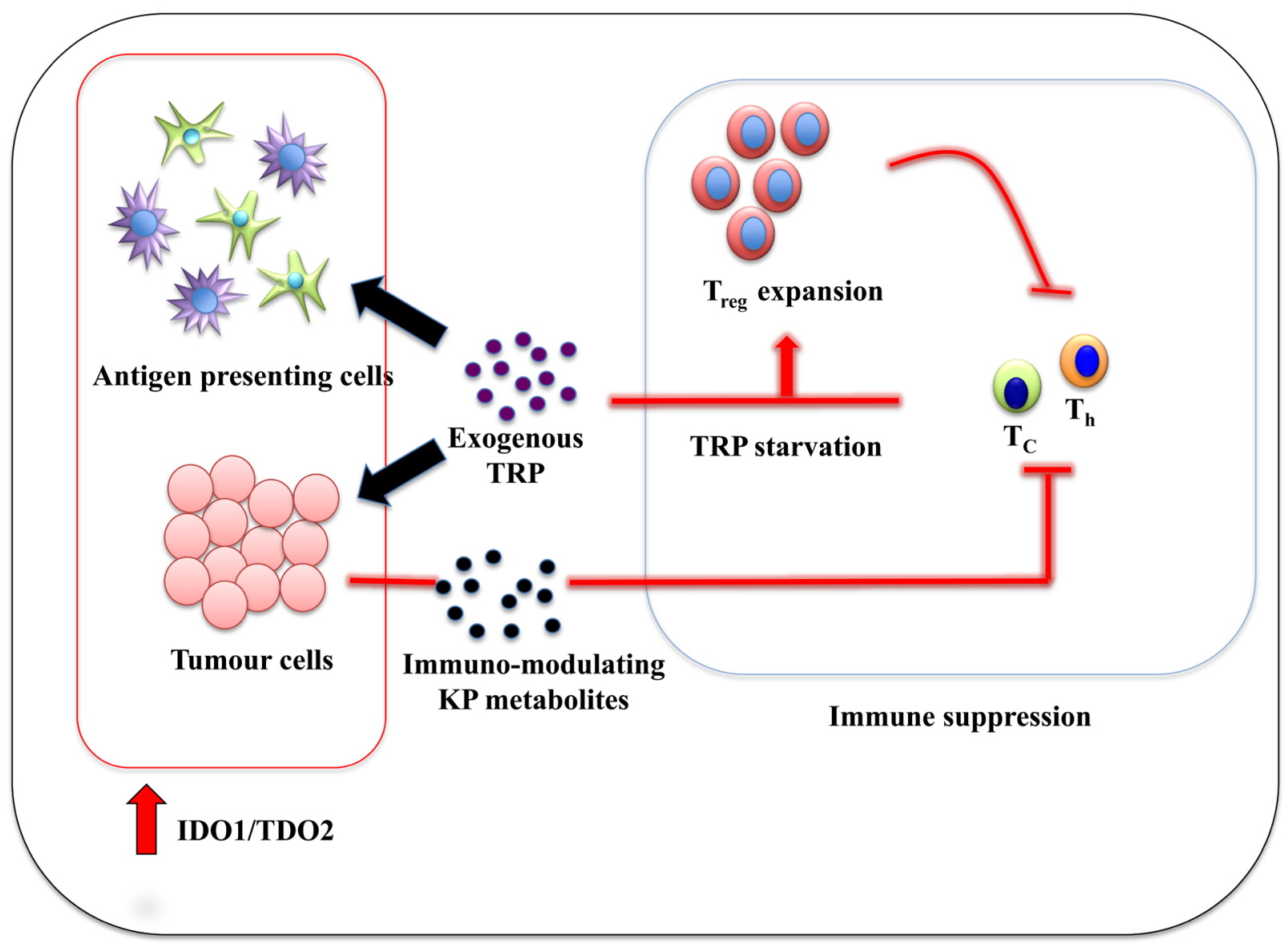

Figure 3: Immune tolerance mechanism by IDO1:TDO2 overexpression in cancer-associated inflammation environment. 
highlights the different roles (pro- and anti-tumorigenic) of elevated IDO1 expression within tumour cells as well as its microenvironment.

\section{KP METABOLITES: INVOLVEMENT IN CANCER IMMUNOBIOLOGY}

\section{KYN}

$\mathrm{KYN}$ is the first catabolite produced from tryptophan by IDO $1 / 2$ and/or TDO2. KYN has been recently identified as an endogenous ligand for the aryl hydrocarbon receptor (AhR) [57], a key ligand-activated transcription factor involved in diverse cellular functions such as cellular differentiation and proliferation. Activation of the AhR by KYN promotes selective expansion of $\mathrm{T}_{\text {regs }}$ due to activation of forkhead box p3 (Foxp3) in naïve T-cells preventing maturation of $T_{h} 17$ cells [58]. Martin-Orozco and colleagues subsequently showed that depletion of the $\mathrm{T}_{\mathrm{h}} 17$ population favoured tumour growth in the lungs of mice injected intravenously with B16-F10 melanoma [59]. Adaptive transfer of antigen-challenged $T_{h} 17$ into tumourbearing mice led to a lower rate of tumour establishment and growth whereas Th17 free mice could not prevent establishment of tumour allografts. The distinct antitumour effect of the $T_{h} 17$ cell subset reflects an ability to enhance DC infiltration and Tc cells immune response [59]. Accordingly, active expansion of $\mathrm{T}_{\text {regs }}$ cells through KYN-AhR activation creates an immune suppressive zone around IDO1 and/or TDO2 expressing tumours.

Enhanced tumour-cell survival and motility also results from KYN-AhR activation. Opitz et al., found that TDO2 expressing (i.e. KYN producing) brain tumour xenografts in AhR-proficient mice had an enhanced tumour growth rate, increased levels of the inflammatory cytokines (IL-1 $\beta$, IL-6 and IL-8) and a decreased number of infiltrating CD8+ cells around tumours with high AhR and TDO2 expression [57]. The persistence of elevated inflammatory cytokines in the microenvironment may lead to chronic IDO1 expression in APC cells such as macrophages and DC and/or tumour cells [60] thereby creating a pro-inflammatory feedback loop promoting tumour growth. Collectively, these studies highlight the importance of the AhR in IDO1 and/or TDO2 expressing tumours and emphasize the role that autocrine production of inflammatory cytokines plays in tumour survival and growth. Whether similar tumour-promoting interactions occur with $\mathrm{KYN}$ and $\mathrm{AhR}$ in BrCa remains unknown but are likely.

\section{3-HAA}

Among the KP metabolites, 3-HAA appears to have the highest capacity to modulate the immune functions of both monocytic cells and lymphocytes. Macrophages treated with 3-HAA, lose their ability to synthesize nitric oxide (NO), due to upstream inhibition of both NF- $\mathrm{KB}$ and inducible nitric oxide synthase (iNOS) activity [61]. Considering that NO production by macrophages is critical to their immune-mediator function, inhibition of NO synthesis may impair macrophage ability to eradicate tumour cells.

Induction of kinase 3- phosphoinositide-dependent protein kinase-1 [62], caspsase-8 and cytochrome $c$ [63] by 3-HAA also induces apoptosis in both $\mathrm{T}_{c}$ and $\mathrm{T}_{h} 1$ populations of effector $\mathrm{T}$ cell [64]. Additionally, 3-HAA also limits cytokine-stimulated Tc proliferation by reducing the number of T-cells entering the cell cycle [65]. The reduction of these two major effector T-cell populations may impair the immune response against KP expressing tumours. More recently, 3-HAA has also been shown to specifically enhance the differentiation of $\mathrm{T}_{\text {regs }}$. A $70 \%$ increase in the number of $\mathrm{T}_{\text {regs }}$ cells is observed after the treatment of naïve T cells with a KP metabolite cocktail containing $10 \mu \mathrm{M}$ of 3-HAA $[63,64]$. This result was further confirmed by both Favre et al. and Zaher et al. who also reported strong $\mathrm{T}_{\text {regs }}$ differentiation in the presence of 3-HAA [66, 67]. In summary, chronic production of 3-HAA by cancer cells may not only lead to progressive loss of competent immune cells but also expansion of immune suppressive cells, dampening immune surveillance and thereby encouraging tumour growth.

\section{Picolinic acid}

Picolinic acid is one of the alternate end products of the KP, resulting from the enzymatic conversion of ACMS by the enzyme ACMSD (Figure 2). Picolinic acid is an endogenous metal chelator for elements such as iron [68]. Based on its iron chelation properties and the fact that other iron chelators such as desferrioxamine exhibit anti-tumour activity, picolinic acid has also been assessed for its anti-tumour activity [69]. Indeed, picolinic acid challenged tumour cells have decreased proliferation rates in vitro [70, 71] and in vivo [72], as compared to untreated control cells. Normal human cells, however, remain unaffected at the same dosage [73].

Picolinic acid is also associated with immune function. Picolinic acid interacts synergistically with IFN- $\gamma$ to augment iNOS production by macrophages [74-76], increasing iNOS mRNA expression by 10 to 15 fold leading to a potent cytotoxic/cytostatic effect. This synergistic interaction was found to last for at least 20 hours. Picolinic acid challenged macrophages have been shown to inhibit tumour growth and increase survival in cancer animal models [76-78]. In addition to macrophage activation, picolinic acid also potently induces macrophage production of the chemokines macrophage inflammatory protein (MIP)- $1 \alpha$ and $-1 \beta$ which also contributes to tumour eradication [79].

QUIN

Under normal physiological conditions, QUIN is the precursor for the production of the essential co-factor 
Table 1A: KP enzymes mRNA expression by microarray database

\begin{tabular}{|l|l|l|l|l|}
\hline & \multicolumn{2}{|l|}{ TCGAOrtal $(\boldsymbol{n}=\mathbf{5 2 6})$} & \multicolumn{1}{l|}{ 185) } \\
\hline & $\begin{array}{l}\text { \%. of KP mRNA } \\
\text { changes }\end{array}$ & $\%$ of elevated mRNA & $\begin{array}{l}\text { \%. of KP } \\
\text { mRNA changes }\end{array}$ & ofevated mRNA \\
\hline IDO-1 & N.A. & N.A. & 32 & 53 \\
\hline TDO2 & 33 & 53 & 34 & 51 \\
\hline KMO & 35 & 61 & 36 & 52 \\
\hline 3HAO & 22 & 49 & 21 & 53 \\
\hline KYNU & 26 & 55 & 23 & 60 \\
\hline ACMSD & 22 & 49 & 24 & 80 \\
\hline QPRT & 36 & 54 & 37 & 49 \\
\hline
\end{tabular}

Table 1B: KP enzymes mRNA expression by human breast cancer subtypes from PAM50 series/cBioPortal

\begin{tabular}{|l|l|l|l|l|l|l|l|l|l|l|}
\hline & \multicolumn{2}{|l}{ Claudin low $(\boldsymbol{n}=\mathbf{8})$} & \multicolumn{2}{l|}{ Basal $(\boldsymbol{n}=\mathbf{8 1})$} & \multicolumn{2}{l}{$\begin{array}{l}\text { HER2 } \\
(\boldsymbol{n}=\mathbf{5 8})\end{array}$} \\
\hline $\begin{array}{l}\text { mRNA } \\
\text { changes }\end{array}$ & $\begin{array}{l}\text { Total } \\
\text { changes } \\
(\%)\end{array}$ & $\begin{array}{l}\text { Elevated } \\
(\%)\end{array}$ & $\begin{array}{l}\text { Total } \\
\text { changes } \\
(\%)\end{array}$ & $\begin{array}{l}\text { Elevated } \\
(\%)\end{array}$ & $\begin{array}{l}\text { Total } \\
\text { changes } \\
(\%)\end{array}$ & $\begin{array}{l}\text { Elevated } \\
(\%)\end{array}$ & $\begin{array}{l}\text { Total } \\
\text { changes } \\
(\%)\end{array}$ & $\begin{array}{l}\text { Elevated } \\
(\%)\end{array}$ & $\begin{array}{l}\text { Total } \\
\text { changes } \\
(\%)\end{array}$ & $\begin{array}{l}\text { Elevated } \\
(\%)\end{array}$ \\
\hline TDO2 & 63 & 100 & 34 & 79 & 41 & 92 & 29 & 25 & 34 & 56 \\
\hline KMO & 25 & 100 & 12 & 60 & 59 & 100 & 36 & 57 & 35 & 49 \\
\hline 3HAO & 25 & 100 & 22 & 67 & 19 & 82 & 21 & 55 & 26 & 17 \\
\hline KYNU & 63 & 100 & 27 & 86 & 34 & 95 & 23 & 34 & 25 & 39 \\
\hline ACMSD & 38 & 0 & 20 & 0 & 19 & 64 & 28 & 89 & 25 & 76 \\
\hline QPRT & 13 & 100 & 31 & 56 & 55 & 94 & 31 & 31 & 35 & 66 \\
\hline
\end{tabular}

Table 1C: KP enzymes mRNA expression in human breast cancer specimens from EMBL-gene Atlas.

\begin{tabular}{|c|c|c|c|c|c|c|}
\hline \multirow{2}{*}{ Disease group } & \multirow{2}{*}{ n value } & \multicolumn{3}{|c|}{ KP enzymes expression } & \multirow{2}{*}{ Array number } & \multirow{2}{*}{ Ref. } \\
\hline & & IDO-1 & TDO2 & KMO & & \\
\hline Normal breast & 143 & & & & \multirow{2}{*}{ E-GEOD- 10780} & \multirow{2}{*}{96} \\
\hline Invasive ductal carcinoma & 42 & & & & & \\
\hline Reduction mammoplastices & 10 & & & & \multirow{4}{*}{ E-TABM-276 } & \multirow{4}{*}{97} \\
\hline Invasive ductual carcinoma & 23 & & & & & \\
\hline $0 \mathrm{~cm}$ away from tumour & \multirow{2}{*}{28} & & & & & \\
\hline 1 to $4 \mathrm{~cm}$ away from tumour & & & & & & \\
\hline Normal breast & 15 & & & & \multirow{2}{*}{ E-GEOD-8977 } & \multirow{2}{*}{98} \\
\hline Invasive ductal carcinoma & 7 & & & & & \\
\hline Ductal carcinoma in situ & 53 & & & & \multirow{2}{*}{ E-GEOD-41194 } & \multirow{2}{*}{99} \\
\hline Invasive breast cancer & 51 & & & & & \\
\hline
\end{tabular}

*Black box: No change in mRNA expression; Green box: up regulation in mRNA expression

$\mathrm{NAD}^{+}$. This reaction is catalysed by the QPRT (Figure 2). QUIN is an agonist of the N-methyl-d-aspartate (NMDA) receptor and in pathophysiological conditions excess QUIN can induce over-activation of the NMDA receptor leading to excitotoxicity in neurodegenerative disorders such as Alzheimer's disease [80]. Quin is also known to be involved in tumour neuropathogenesis and persistence [81-83]. When treated in vitro, Quin increased the proliferation rate of human glioblastoma U343MG cells [84], HT-116 and HT-29 colon cancer cells [85] and
SK-N-SH neuroblastoma [71]. Interestingly, QUIN also increases astroglial production of glial cell line-derived neurotrophic factor [86], which may induce proliferation of cancer cells and increase resistance to chemotherapeutic agents [87]

We showed that QPRT is strongly elevated in higher grade gliomas leading to increased QUIN production, which was significantly associated with poor prognosis [88]. High QUIN levels promote tumour chemo-resistance due to enhanced production of $\mathrm{NAD}^{+}$, a vital substrate for 
Poly [ADP-ribose] polymerase-1 (PARP-1) activation [89], which facilitates repair of reactive oxygen speciesinduced DNA damage and enables cells to recover DNA replication after treatment [90]. In fact, QUIN treated malignant human glioma cells were less sensitive to temozolomide and $\mathrm{H}_{2} \mathrm{O}_{2}$ mediated apoptosis compared to untreated glioma cells [88]. Similarly to 3-HAA, QUIN also modulates the immune response through selective inhibition of $T_{h}$ and $T_{c}$ proliferation and natural killer cell activation [64]. QUIN expression can also increase $\mathrm{T}_{\text {regs }}$ population [67]. These results show that excessive QUIN in the tumour microenvironment may have a significantly detrimental effect on local immuno-surveillance. However, the precise role that QUIN may play in $\mathrm{BrCa}$ remains to be elucidated.

\section{Kynurenic acid}

Kynurenic acid can antagonize QUIN excitotoxicity at NMDA receptors and hence functions as an endogenous neuroprotectant. Whereas 3-HAA and QUIN have immunosuppressive properties that are likely to promote tumour growth [81], kynurenic acid can inhibit adenocarcinoma and renal cell carcinoma cancer cell proliferation in vitro [91]. Inhibition of the mitogen activated protein kinase (MAPK) pathway proteins is one of the possible anti-tumour activities of kynurenic acid [91]. The MAPK pathway promotes several cellular processes including motility, proliferation and survival [92] and is frequently over-activated in human cancer $[93,94]$. Kynurenic acid is also known to up-regulate the expression of p21 Waf1/Cip that induces cell-cycle arrest [95]. Hence the presence of kynurenic acid in the tumour microenvironment might help to limit tumour growth.

\section{REDOX MODULATION BY KP METABOLITES: POTENTIAL INVOLVEMENT IN CANCER GROWTH}

Under certain intracellular or microenvironment conditions KP metabolites have been shown to generate reactive oxygen species (ROS) such as $\mathrm{H}_{2} \mathrm{O}_{2}$ and hydroxyl radical. Formation of ROS has been linked to cancer initiation and progression by inducing lipid peroxidation, DNA damage/mutation and cell proliferation [96]. Indeed, one of the most extensively studied LP products are the 4-hydroxy-2-nonenals (4-HNE) which modulate a number of signaling processes such as Akt pathway involved in cancer initiation and progression [97]

In the presence of transition metals such as copper $\left(\mathrm{Cu}^{2+}\right)$, manganese $\left(\mathrm{Mn}^{2+}\right)$ and iron $\left(\mathrm{Fe}^{3+}\right)$, 3-hydroxykynurenine and 3HAA can be oxidized to generate ROS [98] which is a well-known cause of DNA damage [99]. More recently, it was suggested that 3-hydroxykynurenine mediated cell death independently of caspase-3 activation via p38 MAPK phosphorylation [100]. 3HAA-generated ROS was shown to enhance apoptosis in precursor immune cells such as thymocytes [101] and monocytes [102]. Furthermore, 3HAA can auto-oxidize and generate cinnabarinic acid, which induces apoptosis in thymocytes by an order of magnitude greater than 3HAA [101]. Redox-mediated depletion of these precursor immune cells by 3HAA could lead to tumor persistence due to reduced numbers of mature T-cells. Despite much research supporting a pro-oxidant effect, 3-hydroxylkynurenine and 3HAA also have documented antioxidant properties [103-105]. In fact, 3-hydroxykynurenine and 3HAA has been shown to protect the brain and gliomas against oxidative stress by inhibiting spontaneous lipid peroxidation [106, 107].

QUIN is another KP metabolite that enhances ROS formation in the tumour microenvironment by several mechanisms including formation of redox-active complexes with $\mathrm{Fe}^{2+}$ leading to lipid peroxidation [108]. However, QUIN was also observed to act as an antioxidant in electrochemical studies. Low concentrations of QUIN reduced the rate of ROS production by affecting the $\mathrm{Fe}^{2+/} \mathrm{Fe}^{3+}$ ratios, only at concentrations above pathophysiological levels were pro-oxidant effects observed [109].

These somewhat conflicting observations suggest that the specific environmental milieu may determine the net ROS balance of these metabolites, which is not yet precisely defined in cancer.

\section{EVIDENCE FROM CLINICAL STUDIES}

Up-regulation of $\mathrm{KP}$ metabolism in $\mathrm{BrCa}$ patients was first reported by Rose et al (1967) who found increased kynureninase (KYNU), kynurenine-3-monooxygenase (KMO), and kynurenine aminotransferase-II enzyme activity (Figure 2) in the urine of untreated $\mathrm{BrCa}$ patients compared to controls [110]. While one-third of the patient cohort exhibited higher activity of these three enzymes, the remaining patients had similar enzymatic profiles to the control group. A potential explanation may be that the $\mathrm{KP}$ is differently modulated in the different BrCa subtypes. A later study by Sakurai et al. also detected higher IDO1 activity in the serum of $\mathrm{BrCa}$ patients and higher IDO1 mRNA expression in $\mathrm{BrCa}$ compared to normal tissue [111]. The elevated serum levels and IDO1 expression in tumour correlates to clinical stage, in agreement with another study by Rose et al. showing elevated KP enzyme activity in approximately one third of early cancer patients and in half of advanced BrCa patients respectively [112]. However, increased KP activity in advanced-stage patients was only evident in those with soft tissue metastases. Patients with skeletal metastases displayed normal KP activity, suggesting that KP over-activation may drive proximal tissue invasion but not distal metastasis. There is also evidence of immune system suppression in IDO1positive advanced $\mathrm{BrCa}$ patients as IDO1 expressing breast tumours had higher numbers of infiltrating $\mathrm{T}_{\text {regs }}$ in 
tumour and lymph node metastases [113-115].

A later prospective cohort study showed that KP metabolism returned to near normal levels in $\mathrm{BrCa}$ patients post-mastectomy, with- or without- oophorectomy, further demonstrating the link between tumour presence and KP modulation [116]. More recently, post-surgical renormalization of KP metabolism in BrCa patients was confirmed together with reduced IDO1 activity expression post-chemotherapy [117].

Despite much evidence that IDO1 expression is associated with poor prognosis in BrCa patients, a study of medullary $\mathrm{BrCa}$ patients showed that high IDO1 expression was associated with favourable outcomes [118]. This study agrees with others $[55,56]$ where IDO1 expression was observed in the surrounding dendritic-like monocytes rather than the tumour cells. This again raises the possibility that IDO1 locality determines whether it supports or prevents tumour growth.

\section{Evidence from microarray databank}

\section{Data mining from ex vivo clinical studies}

An early collective and global BrCa study in cBioportal using the Agilent microarray series showed that a total $86.3 \%$ of all $\mathrm{BrCa}$ cases had altered mRNA expression of enzymes in the KP (454 out of $526 \mathrm{BrCa}$ patients, $z$-score of $-1<$ and $>1$, Table 1A) $[119,120]$. Data from the Cancer Genome Atlas (TCGA) confirmed the cBioprotal results and showed a slightly higher percentage of total $91.4 \%$ of patients with altered KP enzyme expression (169 of 185 patients, z-score of $-1<$ and $>1$; Table 1A). However, as both databases did not differentiate BrCa subtype, it is not possible to draw firm conclusions regarding whether specific KP enzymes were up-or down-regulated. Furthermore, the heterogeneous database presentation may dilute subtype specific KP dysregulation evidence.

However, microarray data from patients with invasive breast carcinoma (cBioPortal; PAM50 series) $[119,120]$ (Table $1 \mathrm{~B}, \mathrm{z}$ score $<-1$ and $>1$ ) overcame this limitation. This data showed that the mRNA expression of specific KP enzymes differed substantially by $\mathrm{BrCa}$ subtype. Significantly, the claudin low subtype, exhibited elevated TDO2 and KYNU mRNA expression in more than half of the samples; while a quarter of the samples exhibited elevated $\mathrm{KMO}$ and 3-hydroxyanthranilate 3,4-dioxygenase (3HAO). In the similarly aggressive basal BrCa subtype, both TDO2 and KYNU were also elevated. Elevated expression of TDO2 is indicative of active breakdown of tryptophan leading to increased production of the potent immuno-suppressive metabolite 3-HAA. Intriguingly, ACMSD remained unchanged or downregulated in these subtypes suggesting a KP pathway shift towards quinolinic acid and energy production (thereby facilitating tumour progression) and away from production of the tumour suppressive metabolite picolinic acid. In the HER2-overexpressing BrCa subtype, TDO2, KMO, KYNU and QPRT were elevated similarly to both the claudin-low and basal subtypes in $34 \%$ to $59 \%$ of total specimens. Considering that these subtypes are associated with higher rates of lymph node metastasis, elevation of the early KP enzymes TDO2, KMO and KYNU may promote tumour aggressiveness and metastasis. Interestingly, a portion of HER2 over-expressing specimens had elevated ACMSD, suggesting increased production of anti-tumour picolinic acid metabolite. This is a potentially contradictory observation in a subtype associated with poor prognosis, given the anti-tumour activity of picolinic acid (as described above) antitumorigenic property. However, a potential explanation of this anomaly may be that enhanced picolinic acid by tumour cells could be a potential strategy to chelate additional iron for growth, although there is no data to support this hypothesis.

In contrast, both the low-metastatic risk luminal A and B subtypes showed no changes in KP apart from elevated ACMSD mRNA, which as discussed, could lead to higher concentrations of picolinic acid and a more tumour suppressive KP profile.

Clinical data from the Genes-to-Systems Breast Cancer database [121] was then used to examine the relationship between breast tumour grade and KP mRNA expression profile. This analysis showed that TDO2 expression was higher in well, and moderately differentiated grade 1 and 2 breast tumours, compared to poorly differentiated grade 3 tumours. Increased KP enzymes mRNA expression in invasive breast carcinoma was also observed in the European Molecular Biology laboratory Gene Expression Atlas (EMBL; Table 1C) [122-125]. All invasive carcinoma samples examined in these studies had elevated IDO1, TDO2 and KMO. Interestingly, normal breast epithelial cells in the immediate tumour proximity also showed elevated TDO2 and KMO expression, implying that IDO1/TDO2 expressing tumours have the capability to influence KP activity in surrounding normal tissue. This not only highlights the potential interplay between these three KP enzymes in facilitating tumour invasion, but also suggests that targeting a single KP enzyme may not be optimal for complementary cancer immunotherapy. This agrees with our study demonstrating that the entire pathway is active in human brain tumours that suppresses the antitumour immune response and support tumour growth [57]. Collectively, these data suggest that the elevated KP activity contributes to tumour aggressiveness.

\section{CONCLUSIONS}

Since the discovery of the essential role played by IDO1 in mediating maternal foetal tolerance, a great deal of interest has focused on the roles that IDO1 and other 
KP enzymes may play in cancer immunology. Over the past decade strong evidence has accumulated that confirms that IDO1/TDO2 overexpression in tumour results in tryptophan depletion in the microenvironment, in turn, suppressing the T-cell mediated immune response. Other observations also implicate KP activation in promoting immune evasion. Higher 3-HAA concentrations, resulting from increased KYNU activity, causes reduced iNOS expression in macrophages, impairing their anti-tumour activity. Increased Tregs population caused by KYNAhR activation further promotes immune suppression in the tumour vicinity and increases in QUIN, the NAD ${ }^{+}$ precursor, enhances cell proliferation. Considering these observations, there has been considerable interest in the potential of IDO1 inhibitors to reverse immune evasion with the majority of studies providing positive results.

Clinical data confirms the role of KP activation in $\mathrm{BrCa}$ and provides support for the use of $\mathrm{KP}$ enzyme inhibitor/s in addition to standard chemotherapy regimens. Significantly, KP activation seems to be associated with the more aggressive forms of $\mathrm{BrCa}$ that readily metastasize. Hence, it is possible to speculate that $\mathrm{BrCa}$ patient KP profiling may provide a valuable biomarker potentially capable of discriminating between noninvasive and invasive $\mathrm{BrCa}$. Such methodology may have significant diagnostic, prognostic and/or therapeutic value.

\section{Abbreviations}

1-MT - 1-methyltryptophan

3-HAA - 3-hydroxyanthranilic acid

3HAO - 3-hydroxyanthranilate 3,4-dioxygenase

ACMS - 2-amino-3-carboxymuconate semialdehyde

ACMSD - 2-amino-3-carboxymuconate

semialdehyde decarboxylase

AhR - Aryl hydrocarbon receptor

AMAS - 2-aminomuconic acid 6-semialdehyde

APCs - Antigen presenting cells

$\mathrm{BrCa}$ - Breast cancer

DC - Dendritic cells

ER - Estrogen receptor

Foxp3 - forkhead box p3

IDO1- Indoleamine 2,3 dioxygenase 1

IDO2 - Indoleamine 2,3 dioxygenase 2

iNOS - inducible nitric oxide synthase

KMO - Kynurenine-3-monooxygenase

KP - Kynurenine pathway

KYN - Kynurenine

KYNU - Kynureninase

MAPK - mitogen activated protein kinase

NAD+ - Nicotinamide adenine dinucleotide

NMDA - N-methyl-d-aspartate

NO - Nitric oxide

QUIN - quinolinic acid

PR - Progesterone receptor

ROS - Reactive oxygen species
Tc -Cytotoxic T-cells

TDO2 - Tryptophan 2,3 dioxygenase 2

Th - T helper cells

$\mathrm{TN}$ - Basal/triple negative

Tregs - CD4+CD25+Foxp3+ regulatory T cells

\section{ACKNOWLEDGMENTS}

Cure for life Foundation, Tour de Cure Foundation, The St Vincent Clinic Foundation, The National Health and Medical Research Council (NHMRC), the Australian Research Council (ARC) and The Curran Foundation (Australia) are thanked for supporting our work.

\section{CONFLICTS OF INTERESTS}

The authors declare that they have no competing interests.

\section{Authors' contributions}

$\mathrm{BH}, \mathrm{CKL}$ and GJG conceptualized, drafted and written the manuscript. DBL, LG and AB participated during the draft and proof-read the manuscript. All authors read and approved the final manuscript.

\section{REFERENCE}

1. Ferlay J, Steliarova-Foucher E, Lortet-Tieulent J, Rosso S, Coebergh JW, Comber H, Forman D and Bray F. Cancer incidence and mortality patterns in Europe: estimates for 40 countries in 2012. European journal of cancer. 2013; 49:1374-1403.

2. Perou CM, Sorlie T, Eisen MB, van de Rijn M, Jeffrey SS, Rees CA, Pollack JR, Ross DT, Johnsen H, Akslen LA, Fluge O, Pergamenschikov A, Williams C, Zhu SX, Lonning PE, Borresen-Dale AL, et al. Molecular portraits of human breast tumours. Nature. 2000; 406:747-752.

3. Hergueta-Redondo M, Palacios J, Cano A and MorenoBueno G. "New" molecular taxonomy in breast cancer. Clinical \& translational oncology. 2008; 10:777-785.

4. Sorlie T, Perou CM, Tibshirani R, Aas T, Geisler S, Johnsen H, Hastie T, Eisen MB, van de Rijn M, Jeffrey SS, Thorsen T, Quist H, Matese JC, Brown PO, Botstein D, Lonning $\mathrm{PE}$, et al. Gene expression patterns of breast carcinomas distinguish tumor subclasses with clinical implications. Proceedings of the National Academy of Sciences of the United States of America. 2001; 98:10869-10874.

5. Sotiriou C and Pusztai L. Gene-expression signatures in breast cancer. The New England journal of medicine. 2009; 360:790-800.

6. Fisher B, Costantino J, Redmond C, Poisson R, Bowman D, Couture J, Dimitrov NV, Wolmark N, Wickerham DL, Fisher ER and et al. A randomized clinical trial evaluating 
tamoxifen in the treatment of patients with node-negative breast cancer who have estrogen-receptor-positive tumors. The New England journal of medicine. 1989; 320:479-484.

7. van 't Veer LJ, Dai H, van de Vijver MJ, He YD, Hart AA, Mao M, Peterse HL, van der Kooy K, Marton MJ, Witteveen AT, Schreiber GJ, Kerkhoven RM, Roberts C, Linsley PS, Bernards R and Friend SH. Gene expression profiling predicts clinical outcome of breast cancer. Nature. 2002; 415:530-536.

8. Pegram MD, Konecny G and Slamon DJ. The molecular and cellular biology of HER2/neu gene amplification/ overexpression and the clinical development of herceptin (trastuzumab) therapy for breast cancer. Cancer treatment and research. 2000; 103:57-75.

9. Reis-Filho JS and Tutt AN. Triple negative tumours: a critical review. Histopathology. 2008; 52:108-118.

10. Prat A, Parker JS, Karginova O, Fan C, Livasy C, Herschkowitz JI, He X and Perou CM. Phenotypic and molecular characterization of the claudin-low intrinsic subtype of breast cancer. Breast cancer research. 2010; 12:R68.

11. Creighton CJ, Li X, Landis M, Dixon JM, Neumeister VM, Sjolund A, Rimm DL, Wong H, Rodriguez A, Herschkowitz JI, Fan C, Zhang X, He X, Pavlick A, Gutierrez MC, Renshaw L, et al. Residual breast cancers after conventional therapy display mesenchymal as well as tumor-initiating features. Proceedings of the National Academy of Sciences of the United States of America. 2009; 106:13820-13825.

12. Hennessy BT, Gonzalez-Angulo AM, Stemke-Hale K, Gilcrease MZ, Krishnamurthy S, Lee JS, Fridlyand J, Sahin A, Agarwal R, Joy C, Liu W, Stivers D, Baggerly K, Carey M, Lluch A, Monteagudo C, et al. Characterization of a naturally occurring breast cancer subset enriched in epithelial-to-mesenchymal transition and stem cell characteristics. Cancer research. 2009; 69:4116-4124.

13. Prendergast GC. Immune escape as a fundamental trait of cancer: focus on IDO. Oncogene. 2008; 27:3889-3900.

14. Katz JB, Muller AJ and Prendergast GC. Indoleamine 2,3-dioxygenase in T-cell tolerance and tumoral immune escape. Immunological reviews. 2008; 222:206-221.

15. Pilotte L, Larrieu P, Stroobant V, Colau D, Dolusic E, Frederick R, De Plaen E, Uyttenhove C, Wouters J, Masereel B and Van den Eynde BJ. Reversal of tumoral immune resistance by inhibition of tryptophan 2,3-dioxygenase. Proceedings of the National Academy of Sciences of the United States of America. 2012; 109:24972502.

16. Uyttenhove C, Pilotte L, Theate I, Stroobant V, Colau D, Parmentier N, Boon T and Van den Eynde BJ. Evidence for a tumoral immune resistance mechanism based on tryptophan degradation by indoleamine 2,3-dioxygenase. Nature medicine. 2003; 9:1269-1274.

17. Moffett JR and Namboodiri MA. Tryptophan and the immune response. Immunology and cell biology. 2003;
$81: 247-265$

18. Colabroy KL and Begley TP. Tryptophan catabolism: identification and characterization of a new degradative pathway. Journal of bacteriology. 2005; 187:7866-7869.

19. Takikawa O, Yoshida R, Kido R and Hayaishi O. Tryptophan degradation in mice initiated by indoleamine 2,3-dioxygenase. The Journal of biological chemistry. 1986; 261:3648-3653.

20. Ball HJ, Sanchez-Perez A, Weiser S, Austin CJ, Astelbauer F, Miu J, McQuillan JA, Stocker R, Jermiin LS and Hunt NH. Characterization of an indoleamine 2,3-dioxygenaselike protein found in humans and mice. Gene. 2007; 396:203-213.

21. Ball HJ, Yuasa HJ, Austin CJ, Weiser S and Hunt NH. Indoleamine 2,3-dioxygenase-2; a new enzyme in the kynurenine pathway. The international journal of biochemistry \& cell biology. 2009; 41:467-471.

22. Ren S, Liu H, Licad E and Correia MA. Expression of rat liver tryptophan 2,3-dioxygenase in Escherichia coli: structural and functional characterization of the purified enzyme. Archives of biochemistry and biophysics. 1996; 333:96-102.

23. Takikawa O, Kuroiwa T, Yamazaki F and Kido R. Mechanism of interferon-gamma action. Characterization of indoleamine 2,3-dioxygenase in cultured human cells induced by interferon-gamma and evaluation of the enzymemediated tryptophan degradation in its anticellular activity. The Journal of biological chemistry. 1988; 263:2041-2048.

24. Ren S and Correia MA. Heme: a regulator of rat hepatic tryptophan 2,3-dioxygenase? Archives of biochemistry and biophysics. 2000; 377:195-203.

25. Braun D, Longman RS and Albert ML. A two-step induction of indoleamine 2,3 dioxygenase (IDO) activity during dendritic-cell maturation. Blood. 2005; 106:23752381.

26. Fukunaga M, Yamamoto $Y$, Kawasoe M, Arioka $Y$, Murakami Y, Hoshi M and Saito K. Studies on tissue and cellular distribution of indoleamine 2,3-dioxygenase 2: the absence of IDO1 upregulates IDO2 expression in the epididymis. The journal of histochemistry and cytochemistry. 2012; 60:854-860.

27. Knox WE and Mehler AH. The conversion of tryptophan to kynurenine in liver. I. The coupled tryptophan peroxidaseoxidase system forming formylkynurenine. The Journal of biological chemistry. 1950; 187:419-430.

28. Minatogawa Y, Suzuki S, Ando Y, Tone S and Takikawa O. Tryptophan pyrrole ring cleavage enzymes in placenta. Advances in experimental medicine and biology. 2003; 527:425-434.

29. Suzuki S, Tone S, Takikawa O, Kubo T, Kohno I and Minatogawa Y. Expression of indoleamine 2,3-dioxygenase and tryptophan 2,3-dioxygenase in early concepti. The Biochemical journal. 2001; 355:425-429.

30. Haber R, Bessette D, Hulihan-Giblin B, Durcan MJ and 
Goldman D. Identification of tryptophan 2,3-dioxygenase RNA in rodent brain. Journal of neurochemistry. 1993; 60:1159-1162.

31. Pucci L, Perozzi S, Cimadamore F, Orsomando G and Raffaelli N. Tissue expression and biochemical characterization of human 2-amino 3-carboxymuconate 6-semialdehyde decarboxylase, a key enzyme in tryptophan catabolism. The FEBS journal. 2007; 274:827-840.

32. Salter M, Knowles RG and Pogson CI. Quantification of the importance of individual steps in the control of aromatic amino acid metabolism. The Biochemical journal. 1986; 234:635-647.

33. Munn DH, Zhou M, Attwood JT, Bondarev I, Conway SJ, Marshall B, Brown C and Mellor AL. Prevention of allogeneic fetal rejection by tryptophan catabolism. Science. 1998; 281:1191-1193.

34. Astigiano S, Morandi B, Costa R, Mastracci L, D'Agostino A, Ratto GB, Melioli G and Frumento G. Eosinophil granulocytes account for indoleamine 2,3-dioxygenasemediated immune escape in human non-small cell lung cancer. Neoplasia. 2005; 7:390-396.

35. Brandacher G, Perathoner A, Ladurner R, Schneeberger $\mathrm{S}$, Obrist P, Winkler C, Werner ER, Werner-Felmayer G, Weiss HG, Gobel G, Margreiter R, Konigsrainer A, Fuchs $\mathrm{D}$ and Amberger A. Prognostic value of indoleamine 2,3-dioxygenase expression in colorectal cancer: effect on tumor-infiltrating T cells. Clinical cancer research. 2006; 12:1144-1151.

36. Chamuleau ME, van de Loosdrecht AA, Hess CJ, Janssen JJ, Zevenbergen A, Delwel R, Valk PJ, Lowenberg $\mathrm{B}$ and Ossenkoppele GJ. High INDO (indoleamine 2,3-dioxygenase) mRNA level in blasts of acute myeloid leukemic patients predicts poor clinical outcome. Haematologica. 2008; 93:1894-1898.

37. Ino K, Yoshida N, Kajiyama H, Shibata K, Yamamoto E, Kidokoro K, Takahashi N, Terauchi M, Nawa A, Nomura $\mathrm{S}$, Nagasaka T, Takikawa $\mathrm{O}$ and Kikkawa F. Indoleamine 2,3-dioxygenase is a novel prognostic indicator for endometrial cancer. British journal of cancer. 2006; 95:1555-1561.

38. Okamoto A, Nikaido T, Ochiai K, Takakura S, Saito M, Aoki Y, Ishii N, Yanaihara N, Yamada K, Takikawa O, Kawaguchi R, Isonishi S, Tanaka $\mathrm{T}$ and Urashima $\mathrm{M}$. Indoleamine 2,3-dioxygenase serves as a marker of poor prognosis in gene expression profiles of serous ovarian cancer cells. Clinical cancer research. 2005; 11:6030-6039.

39. Suzuki Y, Suda T, Furuhashi K, Suzuki M, Fujie M, Hahimoto D, Nakamura Y, Inui N, Nakamura H and Chida $\mathrm{K}$. Increased serum kynurenine/tryptophan ratio correlates with disease progression in lung cancer. Lung cancer. 2010; 67:361-365.

40. Takao M, Okamoto A, Nikaido T, Urashima M, Takakura S, Saito M, Saito M, Okamoto S, Takikawa O, Sasaki H, Yasuda M, Ochiai K and Tanaka T. Increased synthesis of indoleamine-2,3-dioxygenase protein is positively associated with impaired survival in patients with seroustype, but not with other types of, ovarian cancer. Oncology reports. 2007; 17:1333-1339.

41. Folgiero V, Goffredo BM, Filippini P, Masetti R, Bonanno G, Caruso R, Bertaina V, Mastronuzzi A, Gaspari S, Zecca M, Torelli GF, Testi AM, Pession A, Locatelli F and Rutella S. Indoleamine 2,3-dioxygenase 1 (IDO1) activity in leukemia blasts correlates with poor outcome in childhood acute myeloid leukemia. Oncotarget. 2014; 5:2052-2064. doi: 10.18632/oncotarget.1504.

42. Muller AJ, DuHadaway JB, Donover PS, SutantoWard E and Prendergast GC. Inhibition of indoleamine 2,3-dioxygenase, an immunoregulatory target of the cancer suppression gene Bin1, potentiates cancer chemotherapy. Nature medicine. 2005; 11:312-319.

43. Belladonna ML, Grohmann U, Guidetti P, Volpi C, Bianchi R, Fioretti MC, Schwarcz R, Fallarino F and Puccetti P. Kynurenine pathway enzymes in dendritic cells initiate tolerogenesis in the absence of functional IDO. Journal of immunology. 2006; 177:130-137.

44. Lee GK, Park HJ, Macleod M, Chandler P, Munn DH and Mellor AL. Tryptophan deprivation sensitizes activated T cells to apoptosis prior to cell division. Immunology. 2002; 107:452-460.

45. Munn DH, Shafizadeh E, Attwood JT, Bondarev I, Pashine $\mathrm{A}$ and Mellor AL. Inhibition of $\mathrm{T}$ cell proliferation by macrophage tryptophan catabolism. The Journal of experimental medicine. 1999; 189:1363-1372.

46. Curti A, Pandolfi S, Valzasina B, Aluigi M, Isidori A, Ferri E, Salvestrini V, Bonanno G, Rutella S, Durelli I, Horenstein AL, Fiore F, Massaia M, Colombo MP, Baccarani $\mathrm{M}$ and Lemoli RM. Modulation of tryptophan catabolism by human leukemic cells results in the conversion of CD25- into CD25+ T regulatory cells. Blood. 2007; 109:2871-2877.

47. Nakamura T, Shima T, Saeki A, Hidaka T, Nakashima A, Takikawa $\mathrm{O}$ and Saito S. Expression of indoleamine 2, 3-dioxygenase and the recruitment of Foxp3-expressing regulatory $\mathrm{T}$ cells in the development and progression of uterine cervical cancer. Cancer science. 2007; 98:874-881.

48. Salaroglio IC, Campia I, Kopecka J, Gazzano E, Orecchia S, Ghigo D and Riganti C. Zoledronic acid overcomes chemoresistance and immunosuppression of malignant mesothelioma. Oncotarget. 2015; 6:1128-1142. doi:10.18632/oncotarget.2731.

49. Fehervari $\mathrm{Z}$ and Sakaguchi S. CD4+ Tregs and immune control. The Journal of clinical investigation. 2004; 114:1209-1217.

50. Field EH, Matesic D, Rigby S, Fehr T, Rouse T and Gao Q. $\mathrm{CD} 4+\mathrm{CD} 25+$ regulatory cells in acquired MHC tolerance. Immunological reviews. 2001; 182:99-112.

51. Friberg M, Jennings R, Alsarraj M, Dessureault S, Cantor A, Extermann M, Mellor AL, Munn DH and Antonia SJ. Indoleamine 2,3-dioxygenase contributes to tumor cell 
evasion of T cell-mediated rejection. International journal of cancer. 2002; 101:151-155.

52. Ozaki Y, Edelstein MP and Duch DS. Induction of indoleamine 2,3-dioxygenase: a mechanism of the antitumor activity of interferon gamma. Proceedings of the National Academy of Sciences of the United States of America. 1988; 85:1242-1246.

53. Yoshida R, Park SW, Yasui H and Takikawa O. Tryptophan degradation in transplanted tumor cells undergoing rejection. Journal of immunology. 1988; 141:2819-2823.

54. Yu WG, Yamamoto N, Takenaka H, Mu J, Tai XG, Zou JP, Ogawa M, Tsutsui T, Wijesuriya R, Yoshida R, Herrmann $\mathrm{S}$, Fujiwara $\mathrm{H}$ and Hamaoka T. Molecular mechanisms underlying IFN-gamma-mediated tumor growth inhibition induced during tumor immunotherapy with rIL-12. International immunology. 1996; 8:855-865.

55. Ishio $\mathrm{T}$, Goto $\mathrm{S}$, Tahara $\mathrm{K}$, Tone $\mathrm{S}$, Kawano $\mathrm{K}$ and Kitano $\mathrm{S}$. Immunoactivative role of indoleamine 2,3-dioxygenase in human hepatocellular carcinoma. Journal of gastroenterology and hepatology. 2004; 19:319-326.

56. Riesenberg R, Weiler C, Spring O, Eder M, Buchner A, Popp T, Castro M, Kammerer R, Takikawa O, Hatz RA, Stief CG, Hofstetter A and Zimmermann W. Expression of indoleamine 2,3-dioxygenase in tumor endothelial cells correlates with long-term survival of patients with renal cell carcinoma. Clinical cancer research. 2007; 13:6993-7002.

57. Opitz CA, Litzenburger UM, Sahm F, Ott M, Tritschler I, Trump S, Schumacher T, Jestaedt L, Schrenk D, Weller M, Jugold M, Guillemin GJ, Miller CL, Lutz C, Radlwimmer B, Lehmann I, et al. An endogenous tumour-promoting ligand of the human aryl hydrocarbon receptor. Nature. 2011; 478:197-203.

58. Mezrich JD, Fechner JH, Zhang X, Johnson BP, Burlingham WJ and Bradfield CA. An interaction between kynurenine and the aryl hydrocarbon receptor can generate regulatory T cells. Journal of immunology. 2010; 185:3190-3198.

59. Martin-Orozco N, Muranski P, Chung Y, Yang XO, Yamazaki T, Lu S, Hwu P, Restifo NP, Overwijk WW and Dong C. T helper 17 cells promote cytotoxic T cell activation in tumor immunity. Immunity. 2009; 31:787-798.

60. Litzenburger UM, Opitz CA, Sahm F, Rauschenbach KJ, Trump S, Winter M, Ott M, Ochs K, Lutz C, Liu XD, Anastasov N, Lehmann I, Hofer T, von Deimling A, Wick $\mathrm{W}$ and Platten M. Constitutive IDO expression in human cancer is sustained by an autocrine signaling loop involving IL-6, STAT3 and the AHR. Oncotarget. 2014; 5:1038-1051. doi:10.18632/oncotarget.1637.

61. Sekkai D, Guittet O, Lemaire G, Tenu JP and Lepoivre M. Inhibition of nitric oxide synthase expression and activity in macrophages by 3-hydroxyanthranilic acid, a tryptophan metabolite. Archives of biochemistry and biophysics. 1997; 340:117-123.

62. Hayashi T, Mo JH, Gong X, Rossetto C, Jang A, Beck L, Elliott GI, Kufareva I, Abagyan R, Broide DH, Lee J and Raz E. 3-Hydroxyanthranilic acid inhibits PDK1 activation and suppresses experimental asthma by inducing T cell apoptosis. Proceedings of the National Academy of Sciences of the United States of America. 2007; 104:1861918624.

63. Fallarino F, Grohmann U, You S, McGrath BC, Cavener DR, Vacca C, Orabona C, Bianchi R, Belladonna ML, Volpi C, Santamaria P, Fioretti MC and Puccetti P. The combined effects of tryptophan starvation and tryptophan catabolites down-regulate $\mathrm{T}$ cell receptor zeta-chain and induce a regulatory phenotype in naive T cells. Journal of immunology. 2006; 176:6752-6761.

64. Fallarino F, Grohmann U, Vacca C, Bianchi R, Orabona C, Spreca A, Fioretti MC and Puccetti P. T cell apoptosis by tryptophan catabolism. Cell death and differentiation. 2002; 9:1069-1077.

65. Weber WP, Feder-Mengus C, Chiarugi A, Rosenthal R, Reschner A, Schumacher R, Zajac P, Misteli H, Frey DM, Oertli D, Heberer M and Spagnoli GC. Differential effects of the tryptophan metabolite 3-hydroxyanthranilic acid on the proliferation of human CD8+ T cells induced by TCR triggering or homeostatic cytokines. European journal of immunology. 2006; 36:296-304.

66. Favre D, Mold J, Hunt PW, Kanwar B, Loke P, Seu L, Barbour JD, Lowe MM, Jayawardene A, Aweeka F, Huang Y, Douek DC, Brenchley JM, Martin JN, Hecht FM, Deeks SG, et al. Tryptophan catabolism by indoleamine 2,3-dioxygenase 1 alters the balance of TH17 to regulatory $\mathrm{T}$ cells in HIV disease. Science translational medicine. 2010; 2:32ra36.

67. Zaher SS, Germain C, Fu H, Larkin DF and George AJ. 3-hydroxykynurenine suppresses CD4+ T-cell proliferation, induces T-regulatory-cell development, and prolongs corneal allograft survival. Investigative ophthalmology \& visual science. 2011; 52:2640-2648.

68. Richardson DR, Kalinowski DS, Lau S, Jansson PJ and Lovejoy DB. Cancer cell iron metabolism and the development of potent iron chelators as anti-tumour agents. Biochimica et biophysica acta. 2009; 1790:702-717.

69. Testa U, Louache F, Titeux M, Thomopoulos P and Rochant H. The iron-chelating agent picolinic acid enhances transferrin receptors expression in human erythroleukaemic cell lines. British journal of haematology. 1985; 60:491502.

70. Fernandez PJ and Johnson GS. Selective toxicity induced by picolinic acid in simian virus 40- transformed cells in tissue culture. Cancer research. 1977; 37:4276-4279.

71. Guillemin GJ, Cullen K, Lim C, Smythe GA, Garner B, Kapoor V, Takikawa $\mathrm{O}$ and Brew BJ. Characterization of the kynurenine pathway in human neurons. Journal of Neuroscience. 2007; 27:12884-12892.

72. Leuthauser SW, Oberley LW and Oberley TD. Antitumor activity of picolinic acid in CBA/J mice. Journal of the National Cancer Institute. 1982; 68:123-126. 
73. Ogata S, Takeuchi M, Fujita H, Shibata K, Okumura K and Taguchi H. Apoptosis induced by niacin-related compounds in K562 cells but not in normal human lymphocytes. Bioscience, biotechnology, and biochemistry. 2000; 64:1142-1146.

74. Bosco MC, Rapisarda A, Reffo G, Massazza S, Pastorino $\mathrm{S}$ and Varesio L. Macrophage activating properties of the tryptophan catabolite picolinic acid. Advances in experimental medicine and biology. 2003; 527:55-65.

75. Melillo G, Cox GW, Radzioch D and Varesio L. Picolinic acid, a catabolite of L-tryptophan, is a costimulus for the induction of reactive nitrogen intermediate production in murine macrophages. Journal of immunology. 1993; 150:4031-4040.

76. Varesio L, Clayton M, Blasi E, Ruffman R and Radzioch D. Picolinic acid, a catabolite of tryptophan, as the second signal in the activation of IFN-gamma-primed macrophages. Journal of immunology. 1990; 145:4265-4271.

77. Ruffmann R, Schlick R, Chirigos MA, Budzynsky W and Varesio L. Antiproliferative activity of picolinic acid due to macrophage activation. Drugs under experimental and clinical research. 1987; 13:607-614.

78. Ruffmann R, Welker RD, Saito T, Chirigos MA and Varesio L. In vivo activation of macrophages but not natural killer cells by picolinic acid (PLA). Journal of immunopharmacology. 1984; 6:291-304.

79. Bosco MC, Rapisarda A, Massazza S, Melillo G, Young $\mathrm{H}$ and Varesio L. The tryptophan catabolite picolinic acid selectively induces the chemokines macrophage inflammatory protein-1 alpha and -1 beta in macrophages. Journal of immunology. 2000; 164:3283-3291.

80. Guillemin GJ and Brew BJ. Implications of the kynurenine pathway and quinolinic acid in Alzheimer's disease. Redox report. 2002; 7:199-206.

81. Adams S, Braidy N, Bess A, Brew BJ, Grant RS, Teo C and Guillemin GJ. The kynurenine pathway in brain tumor pathogenesis. Cancer research. 2012; 72:5649-5657.

82. Prendergast GC. Immune escape as a fundamental trait of cancer: focus on IDO. Oncogene. 2008.

83. Prendergast GC. Cancer: Why tumours eat tryptophan. Nature. 2011; 478:192-194

84. Serio CD, Cozzi A, Angeli I, Doria L, Micucci I, Pellerito S, Mirone P, Masotti G, Moroni F and Tarantini F. Kynurenic Acid Inhibits the Release of the Neurotrophic Fibroblast Growth Factor (FGF)-1 and Enhances Proliferation of Glia Cells, in vitro. Cell Mol Neurobiol. 2005; 25981-993.

85. Thaker AI, Rao MS, Bishnupuri KS, Kerr TA, Foster L, Marinshaw JM, Newberry RD, Stenson WF and Ciorba MA. IDO1 metabolites activate beta-catenin signaling to promote cancer cell proliferation and colon tumorigenesis in mice. Gastroenterology. 2013; 145:416-425 e411-414.

86. Bresjanac M and Antauer G. Reactive Astrocytes of the Quinolinic Acid-Lesioned Rat Striatum Express GFRalpha1 as Well as GDNF in Vivo. Exp Neurol. 2000; 164:53-59.
87. Hansford LM and Marshall GM. Glial cell line-derived neurotrophic factor (GDNF) family ligands reduce the sensitivity of neuroblastoma cells to pharmacologically induced cell death, growth arrest and differentiation. Neurosci Lett. 2005; 389:77-82.

88. Sahm F, Oezen I, Opitz CA, Radlwimmer B, von Deimling A, Ahrendt T, Adams S, Bode HB, Guillemin GJ, Wick $\mathrm{W}$ and Platten $\mathrm{M}$. The endogenous tryptophan metabolite and NAD + precursor quinolinic acid confers resistance of gliomas to oxidative stress. Cancer research. 2013; 73:32253234.

89. Belenky P, Bogan KL and Brenner C. NAD + metabolism in health and disease. Trends in biochemical sciences. 2007; 32:12-19.

90. Kim MY, Zhang T and Kraus WL. Poly(ADP-ribosyl)ation by PARP-1: 'PAR-laying' NAD+ into a nuclear signal. Genes \& development. 2005; 19:1951-1967.

91. Walczak K, Zurawska M, Kis J, Starownik R, Zgrajka W, Bar K, Turski WA and Rzeski W. Kynurenic acid in human renal cell carcinoma: its antiproliferative and antimigrative action on Caki-2 cells. Amino acids. 2012; 43:1663-1670.

92. Chan-Hui PY and Weaver R. Human mitogen-activated protein kinase kinase kinase mediates the stress-induced activation of mitogen-activated protein kinase cascades. The Biochemical journal. 1998; 336 :599-609.

93. Dhillon AS, Hagan S, Rath O and Kolch W. MAP kinase signalling pathways in cancer. Oncogene. 2007; 26:32793290.

94. Wagner EF and Nebreda AR. Signal integration by JNK and p38 MAPK pathways in cancer development. Nature reviews Cancer. 2009; 9:537-549.

95. Walczak K, Turski WA and Rzeski W. Kynurenic acid enhances expression of $\mathrm{p} 21 \mathrm{Waf1/Cip} 1$ in colon cancer HT29 cells. Pharmacological reports : PR. 2012; 64:745-750.

96. Visconti R and Grieco D. New insights on oxidative stress in cancer. Curr Opin Drug Discov Devel. 2009; 12:240-245.

97. Ayala A, Munoz MF and Arguelles S. Lipid peroxidation: production, metabolism, and signaling mechanisms of malondialdehyde and 4-hydroxy-2-nonenal. Oxid Med Cell Longev. 2014; 2014:360438.

98. Goldstein LE, Leopold MC, Huang X, Atwood CS, Saunders AJ, Hartshorn M, Lim JT, Faget KY, Muffat JA, Scarpa RC, Chylack LT, Jr., Bowden EF, Tanzi RE and Bush AI. 3-Hydroxykynurenine and 3-hydroxyanthranilic acid generate hydrogen peroxide and promote alphacrystallin cross-linking by metal ion reduction. Biochemistry. 2000; 39:7266-7275.

99. Hiraku Y, Inoue S, Oikawa S, Yamamoto K, Tada S, Nishino $\mathrm{K}$ and Kawanishi S. Metal-mediated oxidative damage to cellular and isolated DNA by certain tryptophan metabolites. Carcinogenesis. 1995; 16:349-356.

100. Smith AJ, Smith RA and Stone TW. 5-Hydroxyanthranilic acid, a tryptophan metabolite, generates oxidative stress and neuronal death via p38 activation in cultured cerebellar 
granule neurones. Neurotoxicity research. 2009; 15:303310.

101. Hiramatsu R, Hara T, Akimoto H, Takikawa O, Kawabe $\mathrm{T}$, Isobe $\mathrm{K}$ and Nagase F. Cinnabarinic acid generated from 3-hydroxyanthranilic acid strongly induces apoptosis in thymocytes through the generation of reactive oxygen species and the induction of caspase. J Cell Biochem. 2008; 103:42-53.

102. Morita T, Saito K, Takemura M, Maekawa N, Fujigaki S, Fujii H, Wada H, Takeuchi S, Noma A and Seishima M. 3-Hydroxyanthranilic acid, an L-tryptophan metabolite, induces apoptosis in monocyte-derived cells stimulated by interferon-gamma. Ann Clin Biochem. 2001; 38:242-251.

103. Backhaus C, Rahman H, Scheffler S, Laatsch H and Hardeland R. NO scavenging by 3-hydroxyanthranilic acid and 3-hydroxykynurenine: $\mathrm{N}$-nitrosation leads via oxadiazoles to o-quinone diazides. Nitric Oxide. 2008; 19:237-244.

104. Christen S, Peterhans E and Stocker R. Antioxidant activities of some tryptophan metabolites: possible implication for inflammatory diseases. Proceedings of the National Academy of Sciences of the United States of America. 1990; 87:2506-2510.

105. Giles GI, Collins CA, Stone TW and Jacob C. Electrochemical and in vitro evaluation of the redoxproperties of kynurenine species. Biochem Biophys Res Commun. 2003; 300719-724.

106. Latini A, Rodriguez M, Borba Rosa R, Scussiato K, Leipnitz G, Reis de Assis D, da Costa Ferreira G, Funchal C, Jacques-Silva MC, Buzin L, Giugliani R, Cassina A, Radi R and Wajner M. 3-Hydroxyglutaric acid moderately impairs energy metabolism in brain of young rats. Neuroscience. 2005; 135:111-120.

107. Leipnitz G, Schumacher C, Dalcin KB, Scussiato K, Solano A, Funchal C, Dutra-Filho CS, Wyse AT, Wannmacher CM, Latini A and Wajner M. In vitro evidence for an antioxidant role of 3-hydroxykynurenine and 3-hydroxyanthranilic acid in the brain. Neurochem Int. 2007; 50:83-94.

108. Platenik J, Stopka P, Vejrazka M and Stipek S. Quinolinic acid-iron(ii) complexes: slow autoxidation, but enhanced hydroxyl radical production in the Fenton reaction. Free Radic Res. 2001; 34:445-459.

109. Kubicova L, Hadacek F and Chobot V. Quinolinic acid: neurotoxin or oxidative stress modulator? Int J Mol Sci. 2013; 14:21328-21338.

110. Rose DP. The influence of sex, age and breast cancer on tryptophan metabolism. Clinica chimica acta; international journal of clinical chemistry. 1967; 18:221-225.

111. Sakurai K, Amano S, Enomoto K, Kashio M, Saito Y, Sakamoto A, Matsuo S, Suzuki M, Kitajima A, Hirano T and Negishi N. [Study of indoleamine 2,3-dioxygenase expression in patients with breast cancer]. Gan to kagaku ryoho Cancer \& chemotherapy. 2005; 32:1546-1549.

112. Rose DP and Randall ZC. Tryptophan metabolism in early and advanced breast cancer and carcinoma of the cervix. Clinica chimica acta. 1972; 40:276-280.

113. Yu J, Sun J, Wang SE, Li H, Cao S, Cong Y, Liu J and Ren X. Upregulated expression of indoleamine 2, 3 -dioxygenase in primary breast cancer correlates with increase of infiltrated regulatory $\mathrm{T}$ cells in situ and lymph node metastasis. Clinical \& developmental immunology. 2011; 2011:469135.

114. Yu J, Du W, Yan F, Wang Y, Li H, Cao S, Yu W, Shen C, Liu J and Ren X. Myeloid-derived suppressor cells suppress antitumor immune responses through IDO expression and correlate with lymph node metastasis in patients with breast cancer. Journal of immunology. 2013; 190:3783-3797.

115. Mansfield AS, Heikkila PS, Vaara AT, von Smitten KA, Vakkila JM and Leidenius MH. Simultaneous Foxp3 and IDO expression is associated with sentinel lymph node metastases in breast cancer. BMC cancer. 2009; 9:231.

116. Rose DP and Randall ZC. Reassessment of tryptophan metabolism in breast cancer five years after an initial study. Clinica chimica acta. 1973; 45:33-36.

117. Lyon DE, Walter JM, Starkweather AR, Schubert CM and McCain NL. Tryptophan degradation in women with breast cancer: a pilot study. BMC research notes. 2011; 4:156.

118. Jacquemier J, Bertucci F, Finetti P, Esterni B, CharafeJauffret E, Thibult ML, Houvenaeghel G, Van den Eynde B, Birnbaum D, Olive D and Xerri L. High expression of indoleamine 2,3-dioxygenase in the tumour is associated with medullary features and favourable outcome in basallike breast carcinoma. International journal of cancer. 2012; 130:96-104.

119. Cerami E, Gao J, Dogrusoz U, Gross BE, Sumer SO, Aksoy BA, Jacobsen A, Byrne CJ, Heuer ML, Larsson E, Antipin Y, Reva B, Goldberg AP, Sander C and Schultz $\mathrm{N}$. The cBio cancer genomics portal: an open platform for exploring multidimensional cancer genomics data. Cancer discovery. 2012; 2:401-404.

120. Gao J, Aksoy BA, Dogrusoz U, Dresdner G, Gross B, Sumer SO, Sun Y, Jacobsen A, Sinha R, Larsson E, Cerami E, Sander C and Schultz N. Integrative analysis of complex cancer genomics and clinical profiles using the cBioPortal. Science signaling. 2013; 6:pl1.

121. Mosca E, Alfieri R, Merelli I, Viti F, Calabria A and Milanesi L. A multilevel data integration resource for breast cancer study. BMC systems biology. 2010; 4:76.

122. Chen DT, Nasir A, Culhane A, Venkataramu C, Fulp W, Rubio R, Wang T, Agrawal D, McCarthy SM, Gruidl M, Bloom G, Anderson T, White J, Quackenbush J and Yeatman T. Proliferative genes dominate malignancy-risk gene signature in histologically-normal breast tissue. Breast cancer research and treatment. 2010; 119:335-346.

123. Cheng AS, Culhane AC, Chan MW, Venkataramu CR, Ehrich M, Nasir A, Rodriguez BA, Liu J, Yan PS, Quackenbush J, Nephew KP, Yeatman TJ and Huang TH. Epithelial progeny of estrogen-exposed breast progenitor 
cells display a cancer-like methylome. Cancer research. 2008; 68:1786-1796.

124. Karnoub AE, Dash AB, Vo AP, Sullivan A, Brooks MW, Bell GW, Richardson AL, Polyak K, Tubo R and Weinberg RA. Mesenchymal stem cells within tumour stroma promote breast cancer metastasis. Nature. 2007; 449:557-563.

125. Lee S, Stewart S, Nagtegaal I, Luo J, Wu Y, Colditz G, Medina D and Allred DC. Differentially expressed genes regulating the progression of ductal carcinoma in situ to invasive breast cancer. Cancer research. 2012; 72:45744586. 